\title{
Combining ability estimates in $6 \times 6$ half diallel crosses of bread wheat (Triticum aestivium L.)
}

\author{
Aamir Ali Khokhar ${ }^{*}$, Feroz Gul Nizamani ${ }^{2}$, Raza Ali Rind ${ }^{2}$, Mir \\ Muhammad Nizamani ${ }^{1}$, Muhammad Uzair Khokhar ${ }^{3}$, Asad Shah ${ }^{3}$, \\ Abdul Latif Nizamani ${ }^{4}$ and Muhammad Rafique Rind ${ }^{5}$
}

1. Hainan Key Laboratory for Sustainable Utilization of Tropical Bioresources, Institute of Tropical Agriculture and Forestry, Hainan University, Haikou-China

2. Department of Plant Breeding and Genetics, Sindh Agriculture University Tandojam-Pakistan

3. Department of Entomology, Sindh Agriculture University Tandojam-Pakistan

4. Agricultural Education Extension, Agricultural Social Sciences, Sindh Agriculture University Tandojam-

Pakistan

5. Department of Biotechnology, Sindh Agriculture University Tandojam-Pakistan

*Corresponding author's email: aamirkhokhar300@gmail.com

Citation

Aamir Ali Khokhar, Feroz Gul Nizamani, Raza Ali Rind, Mir Muhammad Nizamani, Muhammad Uzair Khokhar, Asad Shah, Abdul Latif Nizamani and Muhammad Rafique Rind. Combining ability estimates in 6 x 6 half diallel crosses of bread wheat (Triticum aestivium L.). Pure and Applied Biology. Vol. 8, Issue 3, pp19801990. http://dx.doi.org/10.19045/bspab.2019.80142

\begin{tabular}{llll}
\hline \hline Received: 25/02/2019 & Revised: 29/06/2019 & Accepted: 31/07/2019 & Online First: 07/08/2019 \\
\hline \hline
\end{tabular}

\section{Abstract}

The six parents of breed wheat (Triticum aestivum L.) were crossed in half a diallelic method, and their fifteen $\mathrm{F}_{1}$ were evaluated for a combination of the ability of yield traits at the Nuclear Institute of Agriculture, Tandojam, during the 2015-2016 agricultural season. Analysis of variance for genotypes, parents, $F_{1}$ hybrids and parents compared to hybrids was significant for all Traits, which showed the presence of significant variability among parents and their hybrids. The results also showed significant differences between parents in their general combining ability (GCA) and hybrids in relation to the specific combining ability (SCA) for all the characters studied. Dispersion GCA and SCA showed the importance of both additive and non-additive genes. However, a large GCA dispersion compared to the SCA dispersion for all traits, except days up to $75 \%$ of maturity and plant height $(\mathrm{cm})$, demonstrated the importance of the additive gene action in inheriting these traits. While the predominance of the non-additive effect of the gene was evident for the inheritance of days up to $75 \%$ of the maturity and growth of the plant $(\mathrm{cm})$. The Aas-2011 variety was the best combiner by day with up to $50 \%$ of the header and days with up to $75 \%$ of maturity; Marvi-2000 for plant height, Sunco for grains spike ${ }^{-1}$, seed index, and plant yield ${ }^{-1}$. Good parents of a common combinator can be used in hybridization and selection programs. Good concrete combiners were; Sunco x Janbaz for days up to $50 \%$ of the course, days up to $75 \%$ of maturity and grain yield ${ }^{-1}$; Sunco x Pak-81 for plant height; WL-711 x Aas-2011 for seed index; Janbaz x Marvi-2000 for grains spike ${ }^{-1}$ and WL-711 x Pak-81 for grain yield plant ${ }^{-1}$.

Keywords: Combining ability; GCA; SCA; Wheat Genotypes; Yield Traits

\section{Introduction}

Wheat (Triticum aestivumL) is the most basic cereal for people all over the world. It is the best vital food product of an estimated
2 billion people, $36 \%$ of the world's population [1]. This is one of the important ancient cultures. However, it can grow in a 
variety of environments and soils, best suited for temperate regions.

Wheat is one of the leading food grains in Pakistan covering the largest area under one crop. It constitutes $10.0 \%$ of value-added in agriculture and $2.1 \%$ of gross domestic production (GDP). During 2017-18, the wheat crop was cultivated on an area of 8,734 thousand hectares showing a decrease of 2.6 percent compared to 8 thousand hectares during the corresponding period last year. Wheat production stood at 25.492 million tonnes during 2017 recording a decline of 4.4 percent over the production of 26.674 million tonnes last year. Wheat accounts for 9.1 percent of the value-added in agriculture and 1.7 percent of GDP of Pakistan. The shortfall in production is attributed to declining in area sown, delayed and prolonged sugarcane crushing season, acute water shortages and fog and smog in the country [2].

Selection efforts have allowed the development of hexaploid wheat of varying degrees with improved yield and grain characteristics. Varieties and modern lines with different morphological and economic characteristics are available as reproductive stock for researchers and manufacturers [3]. Wheat growers develop new varieties with the desired genetic structure to overcome the consumption pressure of an evergrowing population with the intention of increasing the yield potential of wheat [4]. Wheat is considered the main crop of temperate countries, which is used as animal feed and human food since it is the most preferred food crop among grains, which provides humanity with more nutrients than any other crop. Wheat cultivation began in the south of West Asia, but now it is grown everywhere in the world. Currently, wheat is the most common crop found in many countries, and its demand is growing due to its many health benefits. Wheat is rich in essential nutrients, minerals, vitamins, and carbohydrates. In addition to the food crop, wheat is also grown as a commercial crop, since it gives a high yield per unit area [5].
Wheat is a nutrient-rich cereal that plays an important role in ensuring food security, reduces poverty and increases income sources. In order to provide the population with a growing population in 2030, world wheat production is projected to reach to achieve this goal, 100 million metric and wheat production should be increased by 1 million metricsper year [6]. Plant breeders around the world use genetic resources to ful fill the food demand of a growing population. The main goal of the wheat breeding program is to create new highyielding varieties with improved desired qualities. New varieties can be obtained by applying methods such as introduction, selection, hybridization, mutation, and genetic engineering. There are two main studies of any hybrid cultures: heterosis and combining ability [7]. Wheat production is likely to be increased by developing new varieties of the wider genetic base with improved characteristics in various environmental conditions. Various methods for the analysis of all possible crosses and genotypes were developed by earlier researchers [8].

Information about the general combining ability (GCA), specific combining ability (SCA) and the action of genes in the breeding material is a prerequisite for launching an effective wheat breeding program. The diallel analysis is one of the breeding strategies for assessing the combined effects of the ability of genotypes, and also provides information about the genetic mechanisms controlling various traits [9]. Knowledge of GCA and SCA, affecting the crop and its components, is becoming increasingly important for breeders when choosing suitable parents for the development of potential hybrids in many crops [10]. Many researchers have studied the combining ability and genetic structure of bread wheat and hybrid populations using the methods of analysis of the diallele and line $\mathrm{x}$ tester for the components of yield. Some researchers have observed that the grain yield per plant and most of the 
characteristics associated with the yield were under the uncontrolled influence of the gene on the components [11]. While other researchers $[12,13]$ reported thatin addition to most of the genetic distribution of grain yield, crop components were also controlled by additional genes. In addition, the number of shoots, the length of the plant, the length of the spike, the number of beads per spike and the weight of 1000 beads are controlled by partial dominance with an additional type of gene movement [14]. In another study [15] breeding material was assessed using a combined analysis of the ability for the number of grains per spike, 1000 grain weight, and grain yield per plant in bread wheat. They stated that the size of the additive genetic distribution was higher than the nonadditive distribution for all studied properties.

In order to effectively improve the quality and characteristics of wheat yield, breeders must have knowledge of the inheritance of qualitative and agronomic traits. Until now, many wheat breeders have studied heterosis and the ability to combine $F_{1}$ hybrids for various agronomic and qualitative characteristics of wheat [16].

The purpose of the research study was to evaluate the performance of parents and $F_{1}$ hybrids of bread wheat genotypes; to determine general and specific combining ability of parents and $F_{1}$ hybrids for various traits in bread wheat.

\section{Materials and methods}

Six parents (Sunco, WL-711, Janbaz, Aas2011, Pak-81, Marvi-2000) along with fifteen $F_{1}$ hybrids were raised in the experimental zone of the Nuclear Institute of Agriculture (NIA) Tandojamon silt loam soil having an ECe of $1.3 \mathrm{dS}$ m-1, $\mathrm{pH}$ (7.9), Olsen's P (6.7 mg kg-1), O.M. (0.9\%) and $\mathrm{CaCO} 3(10.6 \%)$ during the growing season 2015-16.The experiment was performed in a random complete block design with three replications. Recommended land preparation practices were adopted.All phosphorus and potassium and half of the nitrogen is broadcast and incorporated in the soil before sowing. Remaining nitrogen applied in three splits.

Number of days up to $50 \%$, Days up to $75 \%$ of maturity, Plant height $(\mathrm{cm})$, grains spike 1 , seeds Index (weight 1000 grains, g), Harvest of grain plants ${ }^{-1}(\mathrm{~g})$. Analysis of Variance was carried out using statistical methods [17]. The differences between the parents were determined through the analysis of $F_{1}$ Diallel and the actions of the gene in accordance with the reported method [18] and Method-2, Model-1, adopted by [19].

\section{Days up to $50 \%$ heading}

It was counted in days from sowing to the emergence of $50 \%$ spikes from flag leaf.

\section{Days to $75 \%$ maturity}

Days to $75 \%$ maturity was taken when $75 \%$ of plants showed yellow peduncle, thus reached to $75 \%$ physiological maturity.

\section{Plant height (cm)}

Plant height (excluding awns) was measured from soil surface to the tip of the spike at about half grain filling stage.

Grains spike $^{-1}$ : The total number of seeds of randomly selected spikes were counted and an average number of seeds per spike was recorded.

\section{Seed index (weight of $\mathbf{1 0 0 0}$ grains in g)}

One thousand grains were randomly taken from each selected sample and weighed in grams on electric balance.

\section{Harvest of grain plant $^{-1}$}

After harvesting, each plant was threshed separately with single plant wheat thresher and clean seeds were obtained for laboratory studies. The grains were weighed on an electric balance and yield per plant in gm was recorded.

\section{Result and discussion}

Traits improvements, such as disease resistance and higher yields, have been the goal of wheat breeders for many decades. Traditional reproduction in this regard has played an important role in the development of new varieties, although molecular genetics has also made many developments. The evolution of new varieties with higher yields and increased 
resistance to pathogens and adaptation to new conditions are just a few of the success stories. Although significant progress has been made in improving the traits of wheat, many improvements are still needed. The advantage of hybridization is the introduction of discrete genetic information in a particular variety. One or more traits can be incorporated into the wheat genome, and the expression of these traits can also be regulated.

Thus, the present study was conducted to determine the general combining ability (GCA) andspecific combining ability (SCA) for various economic characteristics of the semi-diallelic crossings of six varieties of bread wheat. The results of the variance analysis are summarized in (Table 1). The average performance of parents, along with fifteen $\mathrm{F}_{1}$ hybrids for different characters, is shown in (Table 2). The effects of GCA and SCA for different features are shown in (Table $3 \& 4$ ) respectively.

\section{Analysis of variance}

Parents, hybrids, parents against hybrids, the ability to combine plants (GCA) and genotypes, which include the unique ability of hybrids, mean squares in the analysis of variance differed significantly for all features, such as days to $50 \%$ heading, days matured up to $75 \%$, plant height, grain spike $^{-1}$, seed index (mass 1000) and grain yield $^{-1}$.These results indicated that all data could be processed for further analysis in order to assess overall GCAs and SCA estimates. The results regarding the average performance of the total combinability (GCA) and the specific combinability (SCA) are discussed here below.

\section{Days to 50\% heading}

Mean frames obtained from the analysis of variance for genotypes, parents, hybrids, and parents differed significantly on days up to $50 \%$ compared to hybrids. The mean squares obtained from the variance analysis revealed very important differences for total combinability (GCA) and specific combinability (SCA).Because parents designate GCA abnormalities, whereas $\mathrm{F}_{1}$ hybrids designate SCA abnormalities, both meanings imply the importance of both additive and non-additive genes controlling days up to $50 \%$ of the course, while GCA abnormalities were higher than SCA, which indicates additive prevalence genes over non-additive. These data are consistent with data [20-22], which also reported that the additive effect of the gene was important to control this trait.

\section{Days to $75 \%$ maturity}

Genotypes, parents, hybrids, parents against hybrids, mean squares from GCA and SCA with variance analysis differed significantly on days up to $75 \%$ of maturity. The importance of GCA and SCA variations indicates the importance of both genetic and non-additive genetic variants; The variance of SCA is higher than the variance of GCA, which indicates the prevalence of non-added gene effects for this feature. These results are consistent with $[20,23,24]$ it also states that nonadded genetic effects are involved in the expression of days up to $75 \%$ of maturity. With regard to performance (Table 2), the Sunco cultivar has a maximum (106.00) days up to $75 \%$ maturity, while the Marvi2000 varieties have early maturity (103.00) with minimum days up to $75 \%$ maturity. Among hybrids, the Pak-81 x Marvi-2000 cross recorded a maximum (110.00) days up to $75 \%$ of the repayment term, while the WL-711 x Aas-2011 cross occupied the minimum (94.00) days up to $75 \%$ of the repayment term. The effects of GCA, summarized in (Table 3) showed that Sunco had the highest undesirable positive effects of GCA among parents - 11.58, while Aas2011 showed the desirable negative effects of GCA (-4.55). Thus, Parent Marvi-2000 was the best overall combinator for early maturity. As for SCA, all hybrid combinations showed positive effects of SCA (Table 4), however, Pak-81 x Marvi2000 (21.77) and WL-711 x Marvi hybrids 2000 (20.27) recorded the highest, but undesirable positive effects of SCA among all F1 hybrids per day up to $75 \%$ of maturity. 
Table 1. Mean squares from diallel analysis for days to $50 \%$ heading, days to $75 \%$ maturity, plant height (cm), grains spike-1, seed index

\begin{tabular}{|c|c|c|c|c|c|c|c|c|}
\hline Traits & $\begin{array}{c}\text { Replication } \\
\text { D.F.=2 }\end{array}$ & $\begin{array}{c}\text { Genotypes } \\
\text { D.F.= 20 }\end{array}$ & $\begin{array}{c}\text { Parent (P) } \\
\text { D.F.=5 }\end{array}$ & $\begin{array}{c}\text { Hybrids (H) } \\
\text { D.F.= 14 }\end{array}$ & $\begin{array}{c}\text { P vs. H } \\
\text { D.F.= 1 }\end{array}$ & $\begin{array}{c}\text { GCA } \\
\text { D.F.= 5 }\end{array}$ & $\begin{array}{c}\text { SCA } \\
\text { D.F.= 15 }\end{array}$ & $\begin{array}{c}\text { Error } \\
\text { D.F.= 40 }\end{array}$ \\
\hline Days to 50\% heading & 0.68 & $29.94^{* *}$ & $9.25^{* *}$ & $28.22^{* *}$ & $157.5^{* *}$ & $27199.28^{* *}$ & $25727.67^{* *}$ & 0.63 \\
\hline Days to 75\% maturity & 0.68 & $58.79^{* *}$ & $3.92^{* *}$ & $72.04^{* *}$ & $147.66^{* *}$ & $56870.80^{* *}$ & $78644.25^{* *}$ & 0.91 \\
\hline Plant height & 5.05 & $234.15^{* *}$ & $226.18^{* *}$ & $252.86^{* *}$ & $12.02^{*}$ & $44799.44^{* *}$ & $59129.68^{* *}$ & 5.85 \\
\hline Grains spike $^{-1}$ & 40.33 & $105.97 * *$ & $49.12^{* *}$ & $71.99^{* *}$ & $865.91^{* *}$ & $27156.84^{* *}$ & $21076.12^{* *}$ & 17.08 \\
\hline Seed index & 58.92 & $55.04^{* *}$ & $61.58^{*}$ & $41.75^{*}$ & $208.42^{* *}$ & $10417.42^{* *}$ & $6499.65^{* *}$ & 30.75 \\
\hline Grain yield plant $^{-1}$ & 4.76 & $96.87^{* *}$ & $27.20^{* *}$ & $20.22^{* *}$ & $1518.23^{* *}$ & $4941.53^{* *}$ & $1354.41^{* *}$ & 1.26 \\
\hline
\end{tabular}

(1000 grain weight in g) and grain yield plant ${ }^{-1}$ in bread wheat (Triticum aestivum $\mathrm{L}$.)

$* *, *=$ Significant at 1 and $5 \%$ probability levels respectively 
Table 2. Mean performance of parents and hybrids for days to $50 \%$ heading, days to $75 \%$ maturity, plant height $(\mathrm{cm})$, grains spike ${ }^{-1}$, seed index and grain yield plant $^{-1}$ inbreadwheat (Triticum aestivum $\mathbf{L}$.)

\begin{tabular}{|c|c|c|c|c|c|c|}
\hline Crosses/Parents & $\begin{array}{c}\text { Days to } \\
\mathbf{5 0 \%} \\
\text { heading }\end{array}$ & $\begin{array}{c}\text { Days to 75\% } \\
\text { maturity }\end{array}$ & $\begin{array}{c}\text { Plant } \\
\text { height } \\
\text { (cm) }\end{array}$ & $\begin{array}{c}\text { Grains } \\
\text { spike-1 }^{-1}\end{array}$ & $\begin{array}{c}\text { Seed } \\
\text { index (g) }\end{array}$ & $\begin{array}{c}\text { Grain yield }_{\text {plant }^{\mathbf{1}}} \\
\text { (g) }\end{array}$ \\
\hline Sunco x Janbaz & 68.33 & 98.67 & 91.50 & 73.00 & 46.05 & 37.00 \\
\hline Sunco x WL-711 & 70.00 & 100.00 & 88.83 & 73.33 & 45.58 & 30.00 \\
\hline Sunco x Aas-2011 & 71.00 & 101.00 & 86.67 & 69.67 & 45.00 & 31.00 \\
\hline Sunco x Pak-81 & 69.00 & 99.00 & 85.00 & 71.33 & 43.76 & 31.80 \\
\hline Sunco x Marvi-2000 & 74.00 & 109.00 & 84.83 & 65.67 & 47.13 & 34.00 \\
\hline Janbaz x WL-711 & 67.67 & 100.00 & 85.00 & 73.33 & 42.36 & 30.00 \\
\hline Janbaz x Aas-2011 & 66.00 & 96.00 & 80.33 & 69.00 & 33.20 & 31.00 \\
\hline Janbaz x PAK-81 & 69.00 & 99.00 & 89.17 & 71.00 & 43.04 & 33.50 \\
\hline Janbazx Marvi-2000 & 71.00 & 106.00 & 81.00 & 77.00 & 46.63 & 29.00 \\
\hline WL-711 x Aas-2011 & 64.00 & 94.00 & 108.33 & 77.33 & 48.52 & 33.00 \\
\hline WL-711 x Pak-81 & 68.00 & 98.00 & 104.33 & 71.67 & 42.14 & 35.00 \\
\hline WL-711 x Marvi-2000 & 74.00 & 108.00 & 81.67 & 73.00 & 45.17 & 29.00 \\
\hline Aas-2011 x Pak-81 & 67.00 & 97.00 & 107.33 & 73.33 & 43.00 & 35.00 \\
\hline Aas-2011x Marvi- & 69.33 & 99.33 & 90.17 & 73.00 & 48.74 & 35.00 \\
\hline 2000 & 75.00 & 110.00 & 92.17 & 75.67 & 45.98 & 29.00 \\
\hline Pak-81 x Marvi-2000 & 69.56 & 101.00 & 90.42 & 72.49 & 44.42 & 32.22 \\
\hline Average & 76.00 & 106.00 & 80.83 & 62.33 & 36.40 & 18.00 \\
\hline Sunco & 74.00 & 105.00 & 87.50 & 59.33 & 39.47 & 19.00 \\
\hline Janbaz & 72.33 & 104.00 & 95.67 & 61.33 & 41.02 & 23.00 \\
\hline WL-711 & 71.00 & 103.33 & 102.83 & 64.67 & 45.39 & 25.00 \\
\hline Aas-2011 & 73.00 & 105.00 & 97.83 & 58.67 & 34.55 & 19.00 \\
\hline Pak-81 & 72.00 & 103.00 & 83.67 & 60.33 & 45.53 & 24.00 \\
\hline Marvi-2000 & 73.06 & 104.39 & 91.39 & 61.11 & 40.39 & 21.33 \\
\hline Average & 1.31 & 1.57 & 5.17 & 6.82 & 6.34 & 1.85 \\
\hline LSD (5\%) & & & & & \\
\hline
\end{tabular}


Table 3. GCA effects of parents for days to $50 \%$ heading, days to $75 \%$ maturity, plant height, grains spike ${ }^{-1}$, seed index and grain yield plant $^{-1}$ in bread wheat (Triticum aestivum L.)

\begin{tabular}{|c|c|c|c|c|c|c|}
\hline Crosses & $\begin{array}{c}\text { Days to 50\% } \\
\text { heading }\end{array}$ & $\begin{array}{c}\text { Days to } \\
\text { maturity }\end{array}$ & $\begin{array}{c}\text { Plant } \\
\text { height }\end{array}$ & $\begin{array}{c}\text { Grains } \\
\text { spike }^{-1}\end{array}$ & $\begin{array}{c}\text { Seed } \\
\text { index }\end{array}$ & $\begin{array}{c}\text { Grain yield } \\
\text { plant }^{-1}\end{array}$ \\
\hline Sunco x Janbaz & -0.26 & 0.31 & 12.05 & 6.95 & 5.94 & 9.51 \\
\hline Sunco x WL-711 & 1.41 & 1.73 & 3.22 & 6.37 & 3.71 & 2.39 \\
\hline Sunco x Aas-2011 & 3.36 & 4.39 & -0.43 & 3.08 & 3.26 & 2.14 \\
\hline Sunco x Pak-81 & -0.22 & 0.23 & -2.12 & 5.41 & 3.43 & 3.72 \\
\hline Sunco x Marvi-2000 & 2.99 & 6.81 & 5.51 & -0.63 & 3.47 & 6.39 \\
\hline Janbaz x WL-711 & 10.11 & 16.10 & 9.88 & 13.24 & 6.69 & 4.97 \\
\hline Janbaz x Aas-2011 & 9.40 & 13.77 & 3.74 & 9.29 & -2.35 & 4.72 \\
\hline Janbaz x PAK-81 & 10.82 & 14.60 & 12.55 & 11.95 & 8.91 & 7.64 \\
\hline Janbazx Marvi-2000 & 11.03 & 18.18 & 12.18 & 17.58 & 9.16 & 3.97 \\
\hline WL-711 x Aas-2011 & 7.41 & 11.85 & 25.57 & 16.70 & 11.21 & 6.60 \\
\hline WL-711 x Pak-81 & 9.82 & 13.68 & 21.55 & 11.70 & 6.26 & 9.51 \\
\hline WL-711 x Marvi-2000 & 14.03 & 20.27 & 6.68 & 12.66 & 5.95 & 3.85 \\
\hline Aas-2011 x Pak-81 & 9.78 & 14.35 & 23.07 & 13.74 & 7.23 & 8.26 \\
\hline Aas-2011x Marvi- & 10.32 & 13.27 & 13.70 & 13.04 & 9.64 & 8.60 \\
\hline 2000 & 14.40 & 21.77 & 15.68 & 16.37 & 8.30 & 3.51 \\
\hline Pak-81 x Marvi-2000 & 0.70 & 0.84 & 2.78 & 3.66 & 6.80 & 0.99 \\
\hline S.E (si) & & & & & & \\
\hline
\end{tabular}

Table 4. SCA effects of $\mathrm{F}_{1}$ hybrids for days to $50 \%$ heading, days to $75 \%$ maturity, plant height, grains spike ${ }^{-1}$, seed index and grain yield plant ${ }^{-1}$ in bread wheat (Triticum aestivum L.)

\begin{tabular}{|c|c|c|c|c|c|c|}
\hline Parents & $\begin{array}{c}\text { Days to } \\
\mathbf{5 0 \%} \\
\text { heading }\end{array}$ & $\begin{array}{c}\text { Days to 75\% } \\
\text { maturity }\end{array}$ & $\begin{array}{c}\text { Plant } \\
\text { height }\end{array}$ & $\begin{array}{c}\text { Grains }_{\text {spike }^{-1}} \\
\text { Seed } \\
\text { index }\end{array}$ & Grain yield plant \\
\hline Sunco & 8.85 & 11.58 & 5.19 & 5.47 & 3.97 & 1.81 \\
\hline Janbaz & -2.19 & -2.80 & -5.31 & -1.41 & -2.23 & -0.78 \\
\hline WL-711 & -2.19 & -2.88 & 0.86 & -0.49 & -0.47 & -0.65 \\
\hline Aas-2011 & -3.15 & -4.55 & 2.34 & -0.87 & -0.59 & 0.60 \\
\hline Pak-81 & -1.56 & -2.38 & 2.36 & -1.53 & -2.01 & -0.32 \\
\hline Marvi-2000 & 0.23 & 1.03 & -5.43 & -1.16 & 1.33 & -0.65 \\
\hline S.E (gi) & 0.25 & 0.30 & 1.01 & 1.33 & 2.47 & 0.362 \\
\hline
\end{tabular}

\section{Plant height (cm)}

Genotypes, parents, hybrids, parents and hybrids, GCA and SCA variance analysis showed that the mean squares showed significant differences in plant height. The importance of GCA and SCA showed that both gene species had an effect on i-e. It controls the heritability of plant height without additives and additives. However, a higher SCA value than the GCA 
dispersion showed the importance of the additive gene effect. These results are consistent with the results of $[25,26]$. Who also reported non-additive actions of genes promoting this character.

Performance as such is presented in (Table 2 ), which shows that the Aas-2011 variety recorded the highest $(102.83 \mathrm{~cm})$ plant heights, while Sunco produced the shortest $(80.83 \mathrm{~cm})$ plants. Among $\mathrm{F}_{1}$ hybrids, the highest plants $(108.33 \mathrm{~cm})$ were measured using a WL-711 x Aas-2011 cross, while Janbaz x Aas-2011 measured short-height plants with $80.33 \mathrm{~cm}$. The results presented in (Table 3) showed Sunco's parents showed the most undesirable positive effects of GCA, equal to 5.19, while Marvi$2000 \quad(-5.43)$ and Janbaz (-5.31) demonstrated the desirable negative effects of GCA. Behavior with short growth is preferable because such plants do not settle and are more sensitive to fertilizers; therefore, negative effects of combining ability are preferable for plant height, especially in wheat. Marvi-2000 and WL711 are considered the best common adders for plant growth with a negative GCA effect on plant height. Of the 15 crosses of dialleles, thirteen hybrids showed positive effects of SCA, while the other two showed the desired negative effects of SCA (Table 4). WL-711 x Aas-2011 discloses the maximum unwanted positive effects of SCA (25,57). However, Sunco x Pak-81 and Sunco x Aas-2011 showed the desired negative effects of SCA -2.12 and -0.43 , respectively.

\section{Number of grains spike ${ }^{-1}(g)$}

Grains per spike are highly dependent on grain yield and are more important for wheat breeders because they play an important role in the development of highyielding varieties, which helps to improve the economy of farmers and the country. The mean squares in the variance analysis showed significant differences for genotypes, parents, hybrids, parents and hybrids, GCA and SCA. The importance of GCA and SCA abnormalities revealed the importance of both genetic and non- additive genetic abnormalities, but GCA variance was dominant. These data correspond to the data $[27,28]$. He also reported that non-chemical gene effects play a role in the expression of grain number per spike.With regard of grain productivity, spike ${ }^{-1}$ (Table 2), the parent Aas-2011 formed the maximum amount of grain spike ${ }^{-1}$ (64.67), while it crosses WL711 x Aas-2011 (77.33) and Janbaz x Marvi- 2000 (77.00) was obtained the maximum number of grains spike- ${ }^{1}$ among $\mathrm{F}_{1}$ hybrids.

The effects of GCA, summarized in (Table 3), showed that the parent effect of Sunco showed a maximum positive effect of GCA equal to 5.47. Because of this, parents can be fruitful in creating variability, on the basis of which effective selection can be made to increase the number of grains per ear. With regard to the effects of SCA, one hybrid combination showed negative effects of SCA, while the remaining fourteen hybrids showed positive effects of SCA for the number of spike ${ }^{-1}$ grains (Table 4). The best concrete combiners with maximum SCA effects were; WL-711 x Ass-2011, Pak81 x Marvi-2000, and Janbaz x Marvi-2000 for grain per spike.

\section{Seed index}

The seed index and yield have a positive correlation, which means that an increase in the seed index per unit will simultaneously increase the seed yield. The mean squares in the variance analysis for genotypes, parents, hybrids, parents, and hybrids, SCA and GCA were significant for seed index. The importance of GCA and SCA has shown the importance of both additives and non-additive genes that control the wheat germ index, but a higher GCA value for seed index compared to SCA showed that the additive type gene effect is valid in the expression of this property. The current results are consistent with the data [20]. They also indicated the dominance of additional genetic effects for the seed index by itself, the average performance of parents, along with $F_{1}$ hybrids, is shown in (Table 2), which indicated that a higher 
seed index was recorded for Marvi-2000 $(45.53 \mathrm{~g})$ and Aas-2011 (45.39 g), respectively. While among $F_{1}$ hybrids, the highest seed index was shown with the cross Aas-2011 x Marvi-2000 (48.74 g), and the second ranger was WL-711 x Aas$2011(48.52 \mathrm{~g})$. The results presented in (Table 3) showed that the parents of Sunco and Marvi-2000 demonstrated the maximum positive effects of GCA, equal to 3.97 and 1.33, respectively, implying that both parents are the best choice for hybridization and selection programs to improve seed index in wheat. Of the 15 diallel crosses, 14 hybrids showed positive effects of SCA, while only one hybrid produced negative effects of SCA. The best concrete combiners were; WL-711 x Aas2011 (11.21), Aas-2011 x Marvi-2000 (9.64) and Janbaz x Marvi-2000 (9.16), but another eleven $\mathrm{F}_{1}$ hybrids also showed quite high positive effects of SCA for this trait, proving their value in using them for the development of hybrid cultures.

\section{Grain yield plant ${ }^{-1}(\mathrm{~g})$}

The grain harvest from a single plant is of unique importance among the characteristics of plants because it plays a very important role in raising the economy of the farmers and the country. The mean values of squares for genotypes, parents, hybrids, parents against hybrids, GCA and SCA were very significant. The significance of both GCA and SCA showed that both additive and non-additive genes were involved in the definition of this trait. However, higher GCA dispersions have shown greater importance of the contribution of the gene in the heredity of the grain yield of plants [21]. Significantly higher deviations of SCA for this trait in wheat are also reported.

The average efficiency of $F_{1}$ hybrids together with their parents (Table 2) showed that the parent Aas-2011 recorded the maximum $(25.00 \mathrm{~g})$ grain yield $^{-1}$, and then Marvi-2000 (24.00 g). Being in a hybrid combination, Sunco $\mathrm{x}$ Janbaz recorded the highest $(37.00 \mathrm{~g})$ grain yield ${ }^{-1}$. In general, it is assumed that the hybrid performance itself is also reflected in the effects of SCA, and in the present case, it is maintained. Regarding the influence of parents on GCA, Sunco and Aas-2011 showed maximum positive effects of 1.81 and 0.60 , respectively (Table 3 ). Thus, Sunco and Aas-2011 were the best overall combinators for this trait, so they are often recommended for use in crossing programs. In general, the plant material showed many variations that could be used in subsequent generations to produce wheat breeding material with excellent characteristics. Regarding the effects of SCA, all 15 diallel crossings demonstrated positive effects of SCA (Table 4). The maximum positive effects of SCA were noted in Sunco $x$ Janbaz and WL-711 x Pak-81, and both hybrids showed the same effects (9.15), but minimal (2.14), but the positive effect of SCA from Sunco x Aas-2011 showed that they can be considered for the development of hybrid cultures. The assumption that $F_{1}$ hybrids can be reflected in the effects of SCA is fully true for grain yield at plant ${ }^{-1}$ in that the highest score, that is, Sunco $\mathrm{x}$ Janbaz and WL-711 x Pak-81, turned out to be the best the scorer $F_{1}$ and SCA effects.

\section{Conclusions}

It is concluded from present research that average squares were important for all characters, because of parents against genotypes, parents, hybrids, and hybrids; this shows that there is considerable genetic variation between parents and hybrids for parents, hybrids and all characters studied. Dispersions of GCA and SCA were significant for all traits, indicating the importance of both additive and nonadditive genes controlling the traits studied.The magnitude of the GCA dispersion was much higher than SCA, which indicates the preponderance of additive effects of genes during the days up to $50 \%$, grain spike ${ }^{-1}$, seed index, and plant yield $^{-1}$. While a higher dispersion of SCA within a few days to $75 \%$ of maturity and plant height indicates a preponderance of dominance genetic effects for these two traits 
Among the parents, Aas-2011 was the best combinator on days to $50 \%$ of the headline and days to $75 \%$ of maturity; Marvi-2000 for plant growth; Sunco for grain spike ${ }^{-1}$, seed index, and grain yield ${ }^{-1}$. These parents can be reliably used in hybridization programs to improve most of the signs of population segregation. Among $\mathrm{F}_{1}$ hybrids, the best specific adders were; Sunco $\mathrm{X}$ Janbaz for days up to $50 \%$ of the course, days up to $75 \%$ of maturity and grain yield -1; Sunco x Pak-81 for plant height; WL711 x Aas-2011 for seed index; Janbaz x Marvi-2000 for grains spike ${ }^{-1}$ and WL-711 $x$ Pak-81 for cereal plants ${ }^{-1}$. These may be hybrids of choice for the exploitation of heterosis and the development of hybrid crops in bread wheat or for the selection of desirable plants from later segregating generations.

\section{Authors' contributions}

Conceived and designed the experiments: AA Khokhar, A Shah \& RA Rind, Performed the experiments: AA Khokhar, FG Nizamani \& RA Rind, Analyzed the data: AA Khokhar \& MM Nizamani, Contributed materials/ analysis/ tools: AL Nizamani \& MU Khokhar, Wrote the paper: AA Khokhar.

\section{References}

1. Breiman A \& Graur D (1995).Wheatevaluation. Israel J Pl Sci 43: 58-95.

2. Pakistan Economic Survey 2017-18

3. Zalewski D (2001). Estimation of combining ability of seven winter wheat lines. Biuletyn Inst Owli-iAklimatyzacji Roslin 218(9): 75-81.

4. Rind RA, Baloch AW, Jatoi WA, Asad MA, Khokhar AA, Nizamani FG, Rind MR, Nizamani AL \& Nizamani MM (2019). Genetic diversity analysis in Pakistani commercial and landrace genotypes of bread wheat. Asian $J$ Agric Biol 7(2): 251-262.

5. Samiullah M, Kalimullah S, Rehmatullah \& Ibrarullah (2014). Profitability of wheat production in DeraIsmail Khan. Pak J Agric Res 27(3): 244-249.
6. Sharma I,Shoran J,Singh G\&Tyagi BS(2011). Wheat improvement in India. Souvenir of 50th all India wheat and barley research workers p. 11. New Delhi.

7. Khokhar AA, Jatoi WA, Nizamani FG, Rind RA, Nizamani MM,Wang HF, Mehmood A \& Khokhar MU (2019). Study of heterosis analysis in $\mathrm{F}_{1}$ population of bread wheat. Pure Appl Boil 8(2): 1757-1770.

8. Kumar S, Kumar N \& Kumar P (2011). Genetic algorithm for network-aware job scheduling in grid environment. 2011 IEEE Recent Advances in Intelligent Computational Systems.

9. Ahmad M, Iqbal M, Shahzad A, Asif M \& Sajad M (2013). Genetic analysis of yield and yield contributing quantitative traits in bread wheat under sodium chloride salinity. J Agric Sci 5(6): 156-163.

10. Kruvadi S (1991). Daillel analysis and heterosis for yield and associated chrachters in durum wheat under upland condition. Turrialba Publ. Canada 41(3): 335-338.

11. Süleyman, S \& Akgüni N (2007). Combining ability and inheritance of some agronomical traits in bread wheat (Triticum aestivu. L.). Ziraat Fakültesi Dergisi 21(41): 104-108.

12. Ahmadi J, Zali AA, Samadi BY, Talaie A, Channaddha MR \& Saeidi A (2003). A study of combining ability and gene effects in bread wheat under drought stress conditions by diallel method. Iranian J Agric Sci 34: 1-8.

13. Joshi SK, Sharma SN, Singhania DL \& Sain RS (2003). Genetic analysis of yield and its component traits in spring wheat, Triticium aestivium L. Acta Agro Hung 52: 139-147.

14. Nazir A, KhaliqI, Farooq J, Mahmood K, Mahmood A, Hussain M \& Shahid M (2014). Pattern of inheritance in some yield related parameters in spring wheat (Triticum aestivum L.). America J Bio Life Sci 2(6): 180-186 
15. Singh BD, Majumdar PK \& Prasad KK (2000). Combining ability for yield and its components in late sown wheat. $J$ Appl Biol 10: 119-126.

16. Kamaluddin RM, Singh LC, Prasad MZ \& Joshi, AK (2007). Combining ability analysis for grain filling duration and yield traits in spring wheat (Triticum aestivum L.). Mol Bio 30: 411-416.

17. Gomez KA \& Gomez AA (1984). Statistical procedure for Agriculture Research. John wiely and sons Inc., 2nd (ed) New York USA.

18. Griffing $B(1956)$.Concept of general and specific combining ability in relation to diallel crossing system. Aust J Bio Sci 9: 463-493.

19. Singh RK \& Choudhary BD (1979). Biometrical Methods in Quantitative Genetic Analysis (Revised. 1979). Kalyani Publisher, New Delhi, pp 191200.

20. Dhadhal BA, Dobariya KL, Ponkia HP \& Jivani LL (2008). Gene action and combining ability over environments for grain yield and its attributes in bread wheat (Triticum aestivum L.). Int J Agric Sci 4(1): 66-72.

21. Akbar M, Anwar J, HussainM, Qureshi MH \& Khan S (2009). Line $\times$ tester analysis in bread wheat (Triticum aestivum L.). J Agric Res 47(1): 411420.

22. Akram Z, Ajmal SU, Khan KS, Qureshi R \& Zubair M (2011). Combining ability estimates of some yield and quality related traits in spring wheat (Triticum aestivum L.). Pak J Bot 43(1): 221-231.

23. Joshi SK, Sharma SN, Singhania DL\& Sain RS (2004). Combining ability in the $F_{1}$ and $F_{2}$ generations of diallel cross in hexaploid wheat (Triticum aestivum L.). Hereditas 141(2): 115121.

24. Malik MFA, Awan SI \& Ali S (2005). Genetic behaviour and analysis of quantitative traits in five wheat genotypes. J Agric Soc Sci 1(4): 313315.

25. Khan MA, Ahmad N, Akbar M, Rehman A \& Iqbal MM (2007). Combining ability analysis in wheat. Pak J Agric Sci 44(1): 1-5.

26. Padhar PR, Madaria RB, Vachhani JH \& Dobariya KL (2010). Combining ability analysis of grain yield and its contributing characters in bread wheat (Triticum aestivum L.) under late sown condition. Int J Agric Sci 6(1): 267272.

27. Nazir S, Khan AS \& Ali Z (2005). Combining ability analysis for yield and yield contributing traits in bread wheat. J Agric and Soc Sci 1(2): 129132.

28. Cifci EA \&Yagdi K (2010). The research of the combining ability of agronomic traits of bread wheat in F1 and $\mathrm{F}_{2}$ generations. UU Ziraat Fakultesi Dergisi (J of Agric Faculty of Uludag Uni) 24(2): 85-92. 